\title{
STRATIGRAPHICAL EVIDENCE OF BALTIC WATER LEVEL CHANGES BETWEEN 8 AND 6 KA BP IN A SMALL LAKE BASIN ON THE COAST OF THE GULF OF FINLAND, SE FINLAND
}

\author{
ARTO MIETTINEN and HANNU HYVÄRINEN
}

\begin{abstract}
ARTO MIETTINEN and HANNU HYVÄRINEN 1997. Stratigraphical evidence of Baltic water level changes between 8 and $6 \mathrm{ka}$ BP in a small lake basin on the coast of the Gulf of Finland, SE Finland. Bull. Geol. Soc. Finland 69, Part 1-2, 43-53.

A sediment core from Lake Saarasjärvi at $19.5 \mathrm{~m}$ a.s.l. in Virolahti near the coast of the Gulf of Finland, SE Finland, was studied for lithology and diatom stratigraphy. The core records changes in the Baltic relative sea level over the last 8000 years. The basin was first isolated from the Baltic slightly before $8000 \mathrm{yrs} \mathrm{BP}$ as a result of the rapid regression towards the end of the Ancylus Lake stage. It was reconnected to the Baltic ca 7600 yrs BP when the transgressive Litorina Sea invaded the basin, and a brackish lagoon was created. The final isolation of the basin from the Baltic occurred ca 6000 yrs ago. The results indicate that the Virolahti area experienced a slow, gradual rise in the relative sea level since about 7600 years ago until between 6500 and 6000 years ago, after which the transgressive trend rapidly turned into a regression still going on. The lake and lagoonal stages in the basin history are clearly reflected in the lithostratigraphy, but the lithological changes are markedly delayed in comparison with the changes in the ecological conditions as indicated by the diatoms.
\end{abstract}

Keywords: sea-level changes, Litorina Sea, Ancylus Lake, lake sediments, lithostratigraphy, diatoms, absolute age, C-14, Holocene, Lake Saarasjärvi, Virolahti, Finland

Arto Miettinen and Hannu Hyvärinen, Department of Geology, P.O. Box 11, FIN-00014 University of Helsinki, Finland

\section{INTRODUCTION}

The site studied (Lake Saarasjärvi, 60 $36^{\circ} \mathrm{N}$, $27^{\circ} 37^{\prime} \mathrm{E}$ ) is a small lake situated in the parish of Virolahti, SE Finland, about $7 \mathrm{~km}$ from the present coast of the Gulf of Finland (Fig. 1). The lake occupies a shallow basin about 15 ha in size and 2-3 metres in depth. It is surrounded by a gentle topography, with extensive cultivated fields on the NW side. The drainage area is about 
$8 \mathrm{~km}^{2}$. At an altitude of $19.5 \mathrm{~m}$ above the sea level, the basin was formerly connected with the Baltic Sea. The present altitude of the threshold is $19,1 \mathrm{~m}$ above sea level, but the threshold was artificially lowered by $40 \mathrm{~cm}$ in the 1940s. The lake was cored in connection with stratigraphical studies aimed to clarify the extent and nature of Holocene relative sea-level changes in the easternmost parts of the Baltic basin. Earlier studies of shore displacement in the area of Virolahti include those by Hyyppä (1937), Salmi (1961) and Valovirta (1965).

According to Hyyppä (1937), the highest limit of the Litorina sea in Virolahti is marked by two separate shorelines, L I at 22-23 m and L II at $20 \mathrm{~m}$ a.s.l. On the basis of an extensive stratigraphical and morphological material from SE Finland and from the Karelian Isthmus, Hyyppä distinguished four main stages in the development of the Litorina Sea, L I - L IV, each representing a transgressive event in the relative sea-level history. His interpretations about sea-level fluctuations were largely based on diatom evidence. By modern standards, however, the quality of the diatom records provided by Hyyppä, sometimes only a few diatoms counted per sample, is clearly insufficient for any firm conclusions.

Salmi (1961) found evidence of two Litorina transgressions in the sediment sequence of Ruokolammensuo, $10 \mathrm{~km}$ SW from Saarasjärvi. According to him the transgression maximum (LI) was $24.5 \mathrm{~m}$ a.s.1. and a second transgression (LII) reached the level of $23.5 \mathrm{~m}$ a.s.l. The conclusions by Salmi were also based on diatom evidence. He identified two percentage peaks of 'salt-water' diatoms in a sequence of brackish Litorina sediments and interpreted these as indications of transgressions. According to modern classification the flora consists exclusively of brackish littoral taxa.

Valovirta (1965) inferred the occurrence of three transgression peaks during the Litorina time on the basis of lithostratigraphical evidence from the Ruotsinsuo mire situated about 30 kilometres W of Saarasjärvi. The diagram of Ruotsinsuo by Valovirta shows three 'transgessive horizons' intercalated in a layer of 'lagoon gyttja' of Litorina age, but no account of the exact nature of these horizons is given.

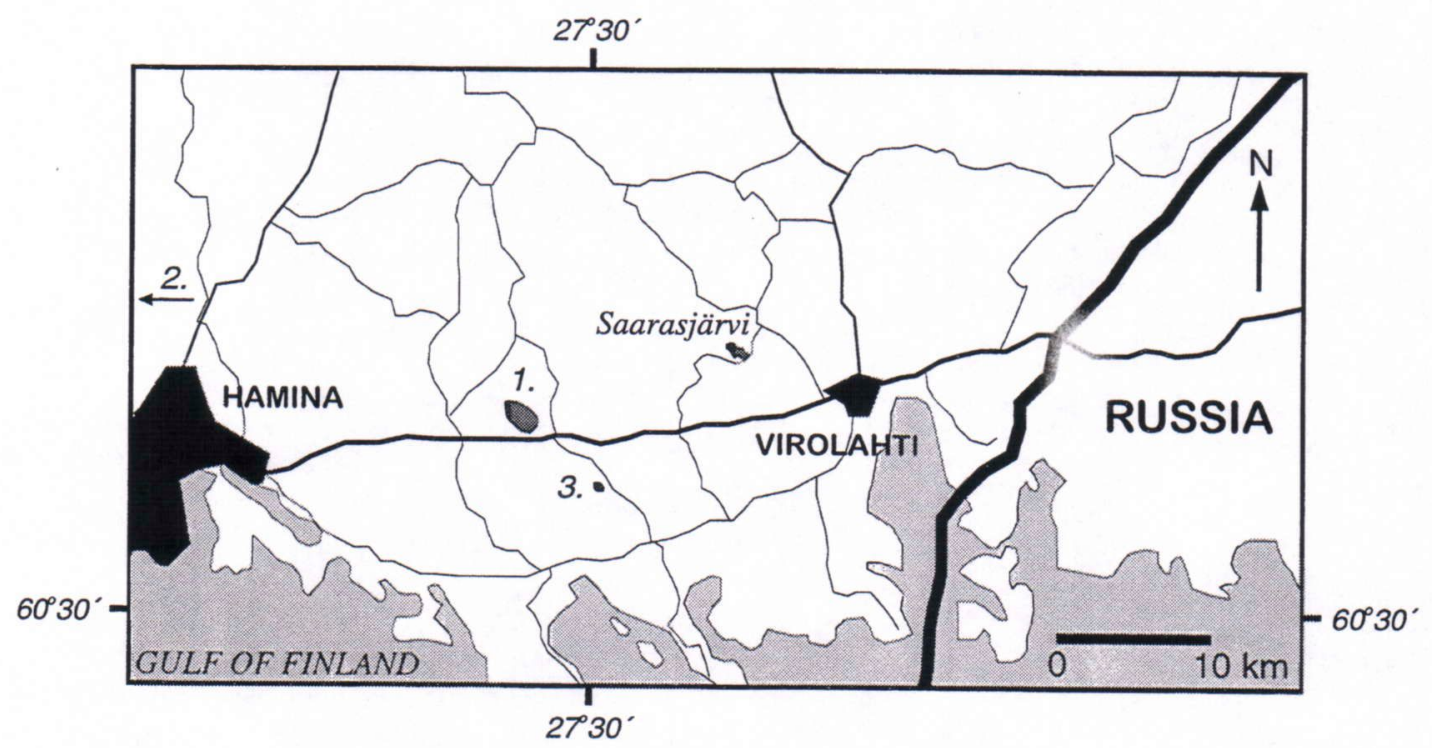

Fig. 1. The location of the study site at Virolahti, SE Finland. The numbers in the figure are the sites referred to in the text: 1. Ruokolamminsuo, 2. Ruotsinsuo, 3. Mustalampi. 
Among the stratigraphical sites in Virolahti investigated by us, the lowermost site not reached by the Litorina Sea is the basin of Mustalampi at $23 \mathrm{~m}$ a.s.1. (no. 3 in Fig.1), situated at about the same isobase for land uplift as Saarasjärvi. Hence, in agreement with the observations by Hyyppä (1937), the Litorina limit in the area must be between 20 and $23 \mathrm{~m}$. The present rate of uplift in Virolahti is $2 \mathrm{~mm} / \mathrm{yr}$.

\section{METHODS}

The basin was sampled from the ice in March 1995 using a Livingstone corer with detachable acrylic tubes (tube length $2 \mathrm{~m}$ and diameter 5 $\mathrm{cm}$ ) and with a Russian peat sampler (chamber length $1 \mathrm{~m}$, diameter $5 \mathrm{~cm}$ ).

The types of sediment were confirmed by measuring the loss-on-ignition at $10 \mathrm{~cm}$ intervals. The samples were dried at $65^{\circ} \mathrm{C}$ overnight and then heated at $550^{\circ} \mathrm{C}$ for 2 hours. LOI\% 2, 6 and 20 were used as the limit values for sediment types clay/gyttja clay, gyttja clay/clay gyttja and clay gyttja/gyttja.

One cubic centimetre of sediment was taken for diatom analysis. The organic matter was dispersed with hydrogen peroxide $\left(\mathrm{H}_{2} \mathrm{O}_{2}\right)$ for over night at $60{ }^{\circ} \mathrm{C}$. The finer material was removed in supension and the coarse material was removed by decanting. The suspension was stirred and about $0,5 \mathrm{ml}$ removed with a pipette and dropped onto a cover glass and allowed to dry. The preparations were fixed in Caedax hartz. At least three hundred diatoms were counted from each sample. The diatom taxonomy used here follows that of Krammer and Lange-Bertalot (1986).

\section{RESULTS AND INTERPRETATIONS}

\section{Lithostratigraphy}

The depth of water at the coring site near the basin centre was $2 \mathrm{~m}$. The coring started at 100 $\mathrm{cm}$ below the sediment surface and stopped at
$600 \mathrm{~cm}$ where a massive, grey silty clay, interpreted as Ancylus clay, was encountered. The following sediment sequence was recorded (Fig. 2):

100-280 cm: brown gyttja with fine plant detritus

280-385 cm: greenish brown clay gyttja

$385-475 \mathrm{~cm}$ : brown gyttja

475-590 cm: greenish brown clay gyttja

$590-600 \mathrm{~cm}$ : grey gyttja clay grading into silty clay

The visual changes are gradual with no sharp boundaries between the layers. Changes in the organic content as defined by loss-on-ignition are also gradual. From the low basal values the organic content rises to about $25 \%$ and drops again to between 14 and $20 \%$. The most pronounced change occurs between 285 and 250 $\mathrm{cm}$ where the organic content rises to about $30 \%$, at which level it then remains. The lithostratigraphy suggests that the Saarasjärvi basin was first cut off from the Ancylus Lake after which it was invaded again by a Baltic transgression before its final isolation from the Baltic waters.

\section{Diatom stratigraphy}

The basal part of the core is dominated by a flora characteristic of the Ancylus Lake stage (Fig. 3), including both planktonic (Aulacoseira islandica, Stephanodiscus rotula) and littoral taxa (Gyrosigma attenuatum, Epithemia hyndmanii, Epithemia spp., Ellerbeckia arenaria). The rapid decline of these taxa at the same time as the organic content rises indicates lowering of the water level until the basin lost contact with the Ancylus Lake. The almost complete disappearance of the Ancylus flora and its replacement by taxa representing a small-lake environment (Tabellaria fenestrata, Cyclotella stelligera, Aulacoseira valida, Eunotia spp., etc.) suggests that the basin became totally isolated from the Ancylus Lake i.e. that the Baltic water level must have been below the basin threshold at the end of the Ancylus stage. 


\section{SAARASJÄRVI}

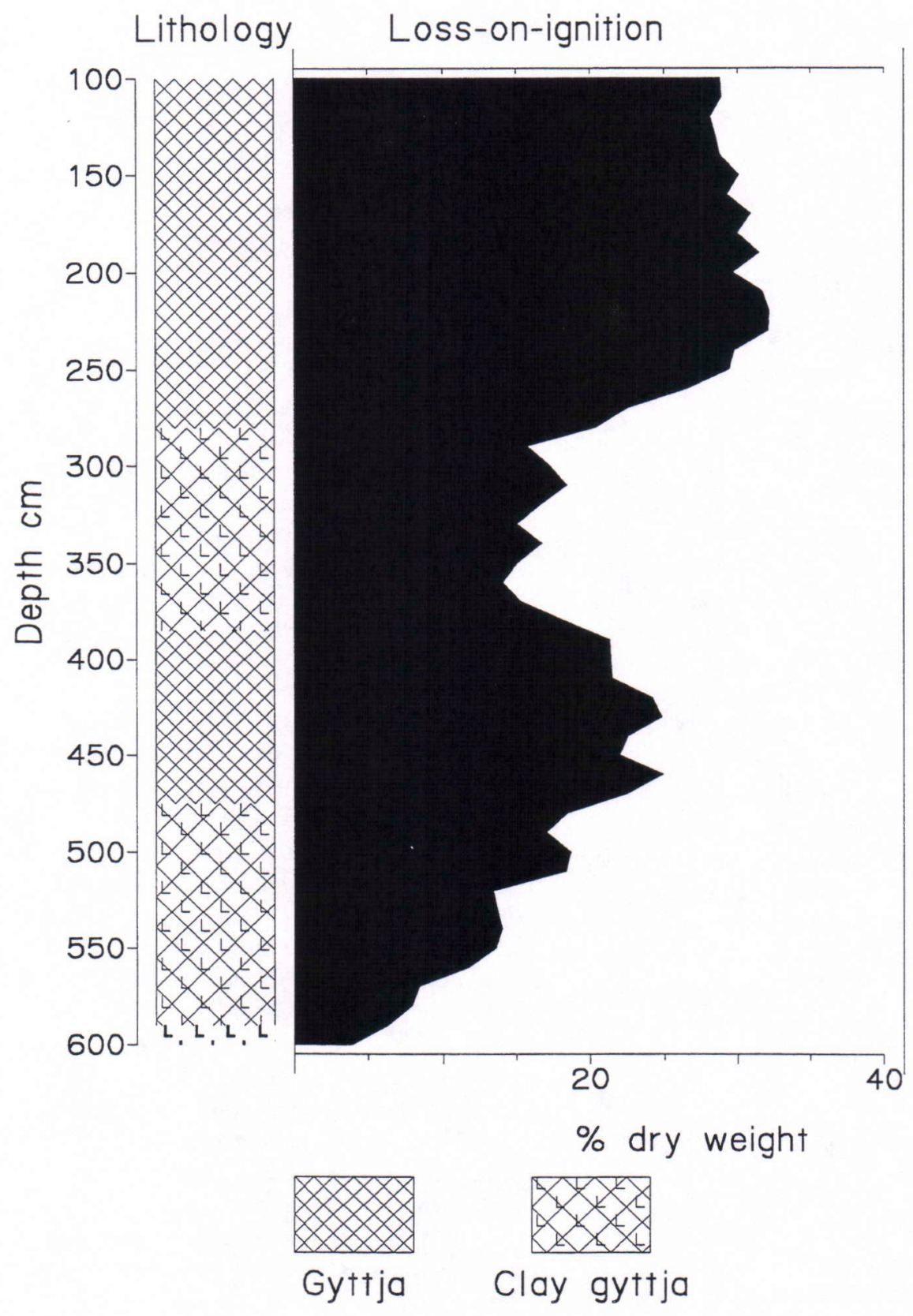

Fig. 2. Lithostratigraphy and loss-on-ignition curve. 
SAARASJÄRVI, Virolahti

19,5 m a.s.I.

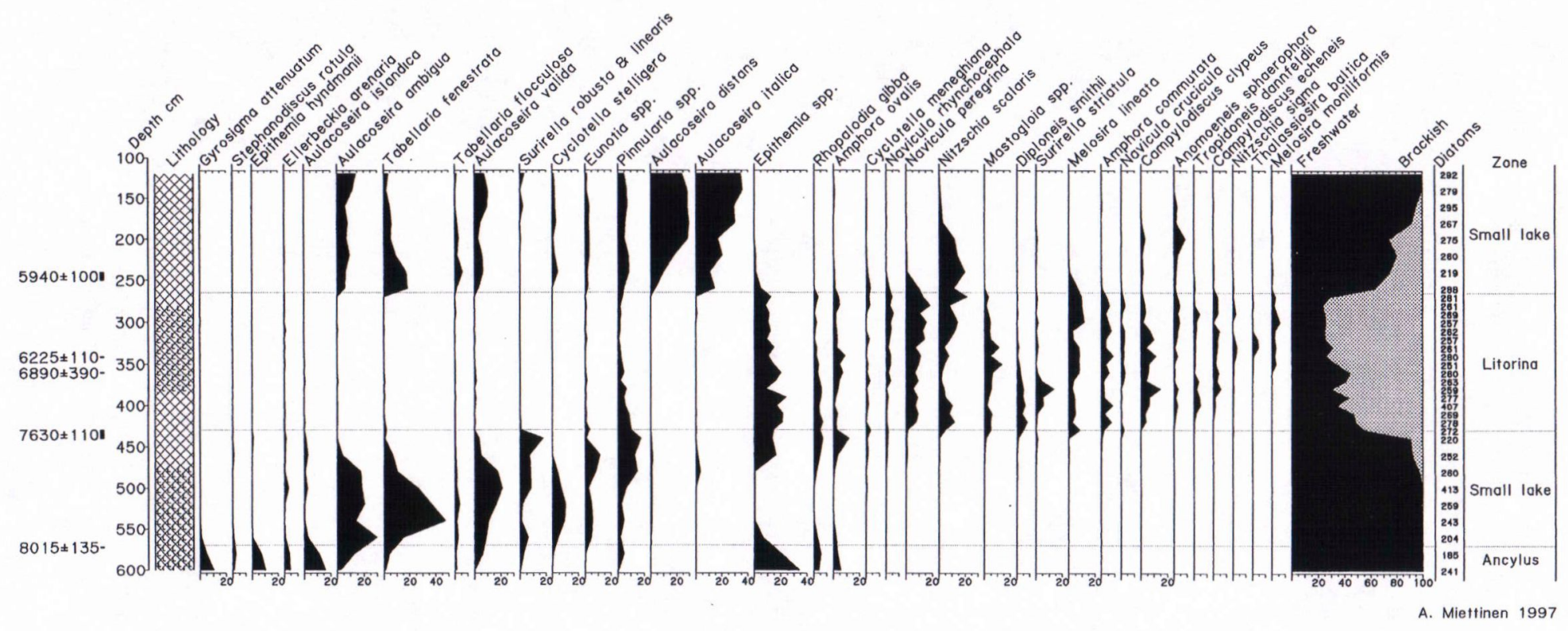

Fig. 3. The diatom diagram of Lake Saarasjärvi.

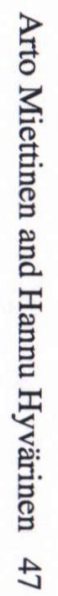


A brackish diatom flora appears at the depth of $430 \mathrm{~cm}$, indicating the invasion of the Saarasjärvi basin by the waters of the Litorina Sea. The appearance or reappearance well below this horizon of several alkaliphilous/halophilous taxa (Epithemia spp., Rhopalodia gibba, Amphora ovalis, Cyclotella meneghiniana, Navicula rhynchocephala) indicates rising nutrient levels before the appearance of the brackish flora and may suggest that the basin threshold was transgressed gradually by a slowly rising Baltic water level. Possibly, a weak connection with the Baltic was established already during the Mastogloia stage, a slightly brackish transitional stage preceding the Litorina stage proper.

The brackish flora consists almost totally by littoral forms, such as Navicula peregrina, Campylodiscus clypeus, Nitzschia scalaris and Mastogloia spp. Pelagic plankton is only represented by Thalassiora baltica, which occurs sparsely with maximum values of ca. $5 \%$ near the middle of brackish section in the core. Judging by the diatoms, the basin has been a lagoon or shallow bay during the Litorina time, with only a narrow connection with the sea. This is also indicated by the abundant occurrence of Fragilaria spp. (excluded from the basic diatom sum).

At a depth of ca $270 \mathrm{~cm}$ the brackish flora is replaced by fresh-water diatoms, mainly the same taxa that grew in the basin before the brackish incursion (Tabellaria fenestrata, Aulacoseira ambigua, A. valida, A. italica and $A$. distans). The rapid increase of the halofobous Tabellaria fenestrata indicates a change to totally fresh conditions (cf. Florin, 1946; Räsänen, 1983), hence the final isolation of the Saarasjärvi basin from the Litorina Sea. Some components of the brackish lagoon flora (Campylodiscus clypeus, Nitzschia scalaris, Anomoeoneis sphaerophora) survived in the basin long after it was cut off from the sea. Nitzschia scalaris is particularly abundant (up to 20\%). The survival of these taxa is probably explained by a relatively high nutrient level in the recently isolated lake. Nitzschia scalaris is known to occur com- monly in small coastal lakes with high nutrient level and does not necessarily indicate brackish conditions (Fontell, 1926; Eronen, 1974; Hyvärinen, 1980). N. scalaris, together with e.g. Campylodiscus clypeus and C. echeneis, has also been found from the sediments of small carbonate-rich inland lakes in Kuusamo, an area of dolomitic bedrock in NE Finland (Hyvärinen, unpublished data).

\section{Comparison of lithology and diatom records}

The lithological units and diatom assemblages relating to events of shore displacement in the basin history are not exactly matched. In diatoms the change from the Ancylus flora to a small-lake flora is very distinct at the depth of $570 \mathrm{~cm}$. However, clay gyttja (LOI 8-20\%) was still being deposited in the basin after the introduction of the small-lake flora. A clear lithological change into a typical small-lake sediment (gyttja, LOI $20 \%$ ) only occurs at around $475 \mathrm{~cm}$ or about a meter above the biostratigraphical isolation horizon. Similarly, as the basin was reconnected with the Baltic, the lithological change is clearly delayed as compared with the appearance of the brackish diatom flora. Only the final isolation of the basin is reflected by nearly parallel changes in the lithology and diatom stratigraphy.

\section{Dating of the water level changes}

Five radiocarbon datings are available from the Saarasjärvi core (Table 1), including two conventional dates on bulk sediment samples and three AMS dates on pieces of wood embedded in the sediments. The radiocarbon dates are given as conventional uncalibrated radiocarbon ages $(\mathrm{T} 1 / 2=5568 \pm 30)$. The bulk samples are from small-lake sediments and the AMS samples from the more silty sediments of the Baltic stages. Fig. 4 shows the age/depth distribution of the datings. 
Table 1. Radiocarbon dates of Lake Saarasjärvi.

\begin{tabular}{lll}
\hline Lab.no: & Depth: & Age (BP): \\
\hline Hel-3906 & $240-250 \mathrm{~cm}$ & $5940 \pm 100$ \\
Hela-58 & $341 \mathrm{~cm}$ & $6225 \pm 110$ \\
Hela-59 & $360 \mathrm{~cm}$ & $6890 \pm 390$ \\
Hel-3907 & $430-440 \mathrm{~cm}$ & $7630 \pm 110$ \\
Hela-60 & $572 \mathrm{~cm}$ & $8015 \pm 135$ \\
\hline
\end{tabular}

The first small-lake stage was relatively shortlived, lasting a few hundred years only. The basal date $(8015 \pm 135)$ represents the replacement of the Ancylus flora by small-lake diatoms, hence the isolation of the basin from the Ancylus Lake waters. The next dated horizon $(7630 \pm 110)$ refers to the introduction of the brackish Litorina flora, but as discussed above, the rising Baltic level may have reached the threshold level of the basin even somewhat earlier.

\section{SAARASJÄRVI / datings}

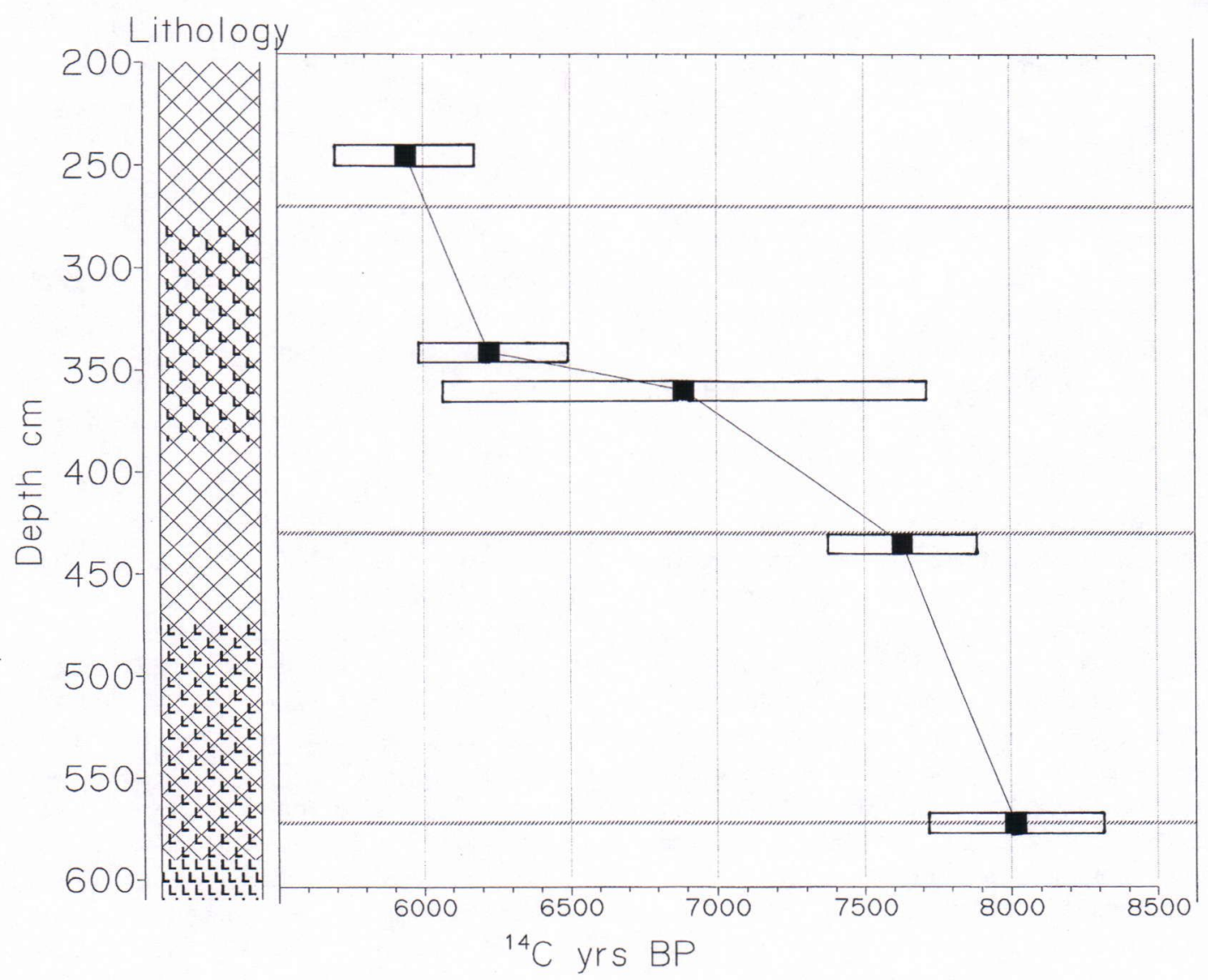

Fig. 4. Age/depth distribution of the datings. 
Two pieces of wood from near the middle of the brackish transgressive layer, at 360 and 341 $\mathrm{cm}$, were dated at $6890 \pm 390$ and $6225 \pm 110 \mathrm{BP}$. The large margin of error in the former dating is due to the small size of the sample. We regard the latter date as reliable and the true age difference between the samples as smaller than it appears to be on the basis of the estimated age of the lower sample. The uppermost date $(5940 \pm 100)$ for a sample of gyttja from immediately above the isolation horizon gives an age of ca $6000 \mathrm{yrs} \mathrm{BP}$ for the final isolation of the basin.

\section{DISCUSSION}

The stratigraphy of Saarasjärvi demonstrates that although events of shore displacement and salinity changes are often clearly recorded in the lithostratigraphy of small basins, this is not automatically the case (cf. Eronen, 1974). The isolation of the Saarasjärvi basin from the Ancylus Lake caused no immediate change in the sediments, neither did the Litorina ingression. In both cases the lithological change follows long after the change in the ecological conditions in the basin, as reflected by the diatom stratigraphy. Obviously, the sediment type is greatly dependent on factors like topography and soils in the catchment. Saarasjärvi has a comparatively large drainage basin including flat areas of clayey and silty sediments in the north. As a result of the Ancylus regression, these sediments were widely exposed and subjected to erosion, which would explain the continued deposition of silty material even after the basin was cut off from the Ancylus Lake. The erosion was then renewed during the Litorina transgression, but as the water level rise was rather slow, it took some time before a clear change in the sediment occurred. These examples illustrate the risks of relying on lithological criteria alone in stratigraphical studies of shore displacement.

The first small-lake stage in the Saarasjärvi basin must represent the period of low Baltic water level at the transition from the Ancylus stage to the Litorina stage. The transgressive trend following the Ancylus regression in the Baltic basin started when the thresholds in Danish Straits were flooded by the rising ocean level, after which the effect of the eustatic rise began in the Baltic shore displacement. The date for the first isolation of Saarasjärvi suggests that the regression minimum occurred about 8000 years ago or slightly later. Saarasjärvi was reconnected about 7600 years ago at the latest, indicating that the Baltic water level had started rising sometime before that date. These results may be compared with the earlier results by Eronen $(1974,1983)$ from the basin of Bastuberg, near Porvoo, about $105 \mathrm{~km}$ west of the present area. The Bastuberg basin was cut off from the Baltic ca 8500 years ago and reconnected ca 7250 years ago, while a sample from the intervening smalllake stage was dated at ca 7960 yr BP. Situated at a relatively higher altitude than Saarasjärvi, Bastuberg was isolated earlier and reconnected later, but overall the results are in good agreement with each other, both indicating a lowwater stage around 8000 years ago. Evidence of a low Baltic water stand at this time is also available from the opposite coast of the Gulf of Finland, from the sites of Sosnovy Bor and Sista Palkino between Narva and St.Petersburg, in the form of buried peats dated at between ca 8270 and 7840 (Kessel \& Punning, 1976; Hyvärinen et al., 1992). A minimum date for the opening of the Danish Straits is provided by the first appearance of brackish diatoms on the coast of Blekinge, south Sweden, ca 8200 years ago (Berglund \& Björck, 1994).

On the basis of lithostratigraphical and diatom evidence, the Saarasjärvi basin experienced a single transgression between ca 7600 and 6000 BP. Our results do not support the earlier conclusions by Hyyppä (1937), Salmi (1961) and Valovirta (1965), who found evidence for repeated Litorina transgressions, or sea-level fluctuations superimposed on the main transgressive trend. The basin is only a few metres below the highest Litorina limit, and was a shallow brackish bay or lagoon during the Litorina time (Fig. 5) as is also apparent from the diatom evidence. 
One would therefore expect any significant fluctuations in the relative sea-level to be reflected in the sediment and diatom record. No signs of such fluctuations were found. The possibility of younger fluctuations after 6000 yrs BP cannot be ruled out. Any secondary fluctuations that might have occurred during the later part of the Litorina stage, after the isolation of the basin, would not be represented in the Saarasjärvi record.

The exact amplitude of the transgression that invaded the Saarasjärvi basin cannot be deter- mined, but an approximate figure may be given. Judging by the short duration of the first smalllake stage, the Baltic water level during the regression minimum, was probably not far below the basin threshold. The absence of Litorina sediments from the Mustajärvi basin, mentioned above, sets the highest possible limit of the transgression at $23 \mathrm{~m}$. Hence, the amplitude cannot have been more than 4-5 metres, and probably it was less.

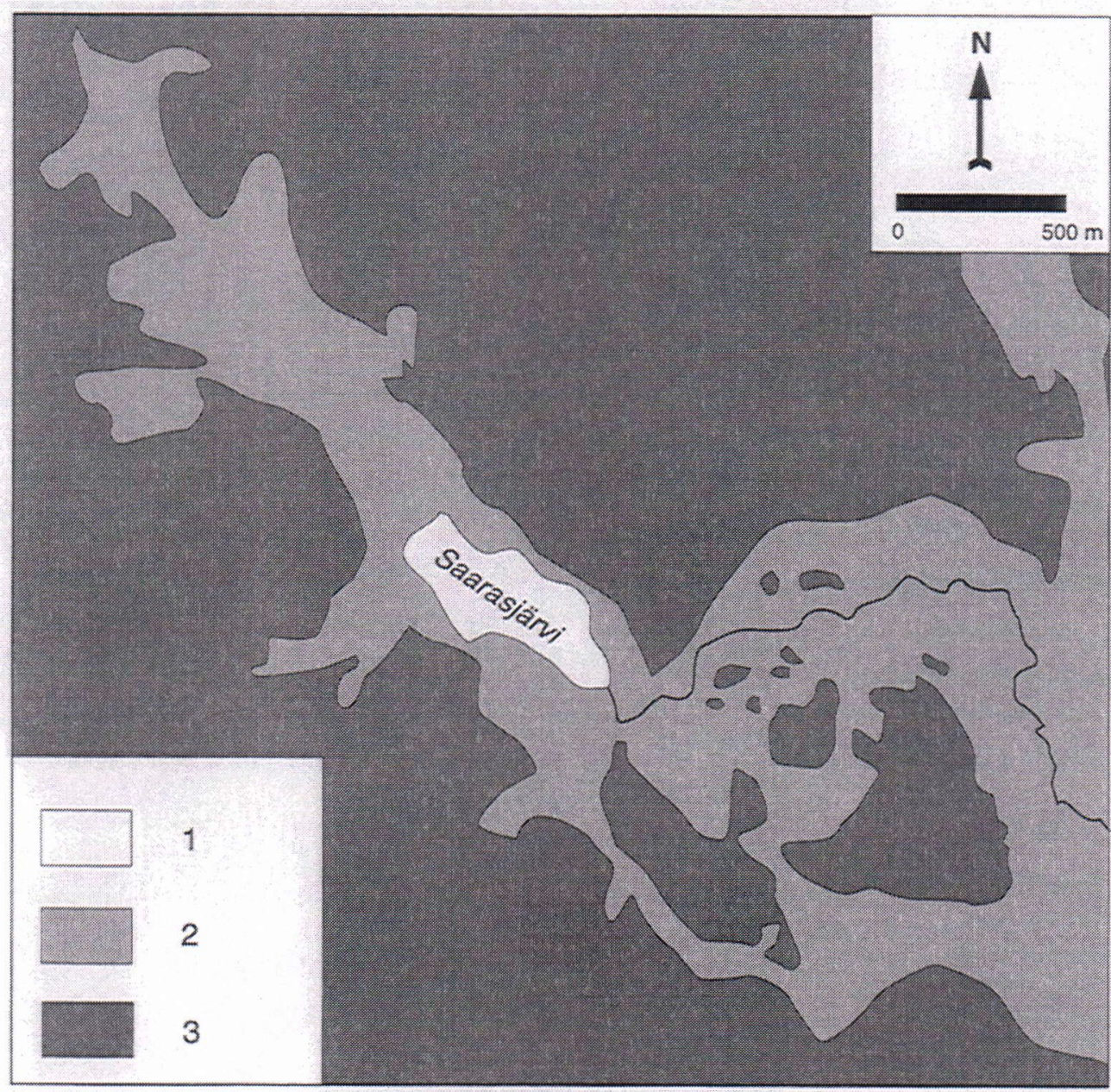

Fig. 5. Paleogeographical map showing the coastline in Saarasjärvi area during the 6500-6000 BP. 1. Lake Saarasjärvi at present, 2. The coastline of the Litorina Sea about 6500-6000 BP, 3. The area above Litorina limit. 
It is not possible to say at which point exactly the transgressive trend turned into regression. The diatom flora is throughout consistent with a shallow lagoon environment, with no clear indications of changes in depth or salinity. The brief appearance of the pelagic taxon Thalassiora baltica at $360 \mathrm{~cm}$, however, may indicate an interval of a freer communication between the Saarasjärvi lagoon and the Baltic, hence culmination of the transgression. We conclude that the culmination must have occurred between 6500 and 6000 yrs BP.

In summary, the data from the Saarasjärvi core indicate first a regression of the relative Baltic water level until about 8000 yrs BP, followed by a gradual, slow rise since between 8000 and 7600 until between 6500 and 6000 yrs BP, after which the transgession turned into a comparatively rapid regression.

The transgression peak would be expected to occur at different times in different areas depending on the local glacio-isostatic uplift, becoming younger as the rate of uplift diminishes (e.g. Eronen, 1974; Hyvärinen et al.,1992). In the easternmost parts of the Gulf of Finland, in the St.Petersburg area (Litorina limit ca $10 \mathrm{~m}$ a.s.1.), the youngest dates obtained for peats or lacustrine sediments transgressed by the Litorina Sea are in the neighbourhood of 6000 yrs BP (Kessel \& Punning, 1976), indicating that the transgression culminated at or after that date. In the Blekinge area in south Sweden, with about the same altitude for the Litorina limit as the St.Petersburg area, the transgession peak occurred between 6000 and 5000 yrs BP (Berglund \& Björck, 1994). In the Porvoo - Helsinki area (Litorina limit ca $30 \mathrm{~m}$ ) the transgessive trend seems to have peaked clearly earlier, closer to 7000 yrs BP (Eronen, 1983). Our estimated date of between 6500-6000 yrs BP for the transgression peak at Saarasjärvi (Litorina limit ca $23 \mathrm{~m}$ ) would fit well in to this picture.

ACKNOWLEDGEMENTS: Our thanks are due to The Dating Laboratory of the University of Helsinki, lead by Högne Jungner, for the radiocarbon dating, and to Matti Eronen for cooperation in the field work. Two anonymous referees provided helpful comments. The study was financed by the Academy of Finland (Grant No. 31393). 


\section{REFERENCES}

Berglund, B. \& Björck, S. (1994) Late Weichselian and Holocene shore displacement in Blekinge, SE Sweden. Acta Universitatis Nicolai Copernici. Geografia 27 - Nauki Matematyczno-Przyrodnicze - Zeszyt 92, 75-95.

Eronen, M. (1974) The history of the Litorina Sea and associated Holocene events. Societas Scientiarum Fennica, Commentationes Physico-Mathematicae 40, 79-195.

Eronen, M. (1983) Late Weichselian and Holocene shore displacement in Finland. In: Smith, D. E. \& Dawson, A. G. (eds): Shorelines and Isostasy. Institute of British Geographers, Special Publication 16, 183-207. Academic Press.

Florin, M. B. (1946) Clypeusfloran i postglaciala fornsjölagerföljder i östra Mellansverige. Geologiska Föreningen i Stockholm Förhandlingar 68, 429-458.

Fontell, C. W. (1926) Om brak- och saltvatten- diatomacéers förekomst $\mathrm{i}$ sött vatten i närheten av kusten. Acta Societatis pro Fauna \& Fennica 55, 3-21.

Hyvärinen, H. (1980) Relative sea-level changes near Helsinki, southern Finland, during early Litorina times. Bulletin of the Geological Society of Finland 52, 207-219.
Hyvärinen, H., Kessel, H. \& Raukas, A. (1992) Mastogloia and Litorina Seas. In: Raukas, A. \& Hyvärinen, H. (eds): Geology of the Gulf of Finland, 296-312. Estonian Academy of Sciences, Tallinn (in Russian, with English summary).

Hyyppä, E. (1937) Post-glacial changes of shore-line in South Finland. Bulletin de la Commission Géologique de Finlande 120, 225 pp.

Kessel, H. \& Punning, J.-M. (1976) On the age of maximal transgression of the Litorina Sea in Leningrad District. Eesti NSV Teaduste Akadeemia toimestised 23, Keemia - Geoloogia 1976, No 3, 222-229 (In Russian, with English summary).

Krammer, K. \& Lange-Bertalot, H. (1986) Süsswasserflora von Mitteleuropa. Bacillariophyceae 1-4. Gustav Fischer Verlag, Stuttgart-New York.

Räsänen, M. (1983) Ahvenanmaan järvialtaissa 1900luvulla tapahtuneiden veden suolapitoisuusmuutosten vaikutus altaiden limnologiaan ja piilevälajistoon. Turun yliopiston maaperäosaston julkaisuja 49, 45 pp.

Salmi, M. (1961) Two Littorina transgressions in Virolahti, southeastern Finland. Bulletin de la Commission Géologique de Finlande 196, 417-436.

Valovirta, V. (1965) Zur Spätquartären Entwicklung Südost-Finnlands. Bulletin de la Commission Géologique de Finlande 220, 1-101. 